\title{
When a city must be a tree: rethinking the spatial approach to fighting epidemics based on the notion of 'intermediate confinement'
}

\author{
Jose Carpio-Pinedo ${ }^{1}$ Elisa Pozo Menéndez ${ }^{1}$. Francisco José Lamíquiz Daudén ${ }^{1}$ - Ester Higueras García ${ }^{1}$
}

Accepted: 15 February 2021 / Published online: 5 March 2021

(c) The Author(s), under exclusive licence to Springer Nature Limited 2021

\begin{abstract}
Principles of sustainability defend compactness, density and diversity as main characteristics of the optimal development of cities. These factors support public transport efficiency, economic activity, accessibility to equipments and services, proximity and walkability of streets and social exchanges in open public spaces. The Covid-19 pandemic crisis has called into question these factors perceived as booster of infections. However, dense and compact cities can also be the synonym of a more efficient provision of services, along with solidarity networks and creative solutions to fight the sanitary and economic crisis. Based on Alexander's (1965) concepts of 'tree' and 'semi-lattice', this study aims to identify areas in the urban tissue that could be self-sufficient, that is functionally autonomous to manage epidemics from the neighbourhood scale. Encouraging healthier lifestyles during lockdown is fundamental for social resilience. What alternative spatial approach to fighting epidemics could perform better? How could an "intermediate confinement" based on self-sufficiency and the promotion of healthier environments become a major priority for action? The analysis of Madrid (Spain) offers a suitable case study due to its density, diversity and high contagiousness during the Covid-19 crisis, revealing also some issues to apply such 'intermediate confinement' strategy, due to major spatial imbalances.
\end{abstract}

Keywords Network analysis $\cdot$ Urban Health $\cdot$ Neighbourhood Unit $\cdot$ Walkable city $\cdot$ Pandemics $\cdot$ Covid-19

\section{Introduction}

The sheer essence of the city implies a rapid spread of viruses. Understood as "the being together of strangers" (Young 1990), as "a human settlement in which strangers are likely to meet" (Sennett 1977, p. 39), or as a "large, dense, and permanent settlement of socially heterogeneous individuals" (Wirth 1969, p. 148), the city is a virus-welcoming arena, which hosts countless common face-to-face interactions, and where simple space-sharing (even asynchronous)

Elisa Pozo Menéndez

e.pozo@upm.es

Jose Carpio-Pinedo

jose.carpio@upm.es

Francisco José Lamíquiz Daudén

francisco.lamiquiz@upm.es

Ester Higueras García

ester.higueras@upm.es

1 Escuela Técnica Superior de Arquitectura de Madrid, Universidad Politécnica de Madrid, Avenida Juan de Herrera 4, 28040 Madrid, Spain can be contagious. City dwellers typically build complex social networks that show distinct properties (Batty 2013, 2020), two of which are crucial in pandemic times. First, the existence of many 'weak ties' (Granovetter 1973) linking heterogeneous groups. Second, the redundancy and resilience of networks, meaning that any pair of individuals are communicated by not one but many social chains. These two properties explain why diseases like Covid-19 spread rapidly and exponentially, and why it is impossible to stop a virus by identifying and blocking specific few links, types of interaction, or by targeting key super-spreader individuals or places (Batty 2020). On the other hand, the same two properties partly explain some of the wonderful phenomena unique to cities, such as creativity, innovation, solidarity and the respect towards social diversity (Fincher and Iveson 2008; Mumford 1938, p. 457).

With regards to the benefits of cities, one of the most successful authors in grasping and communicating these concepts was Christopher Alexander, who asserted that "a city is not a tree", but a 'semi-lattice' (1965). These two concepts are different metaphors describing the shape of urban systems from a structuralist viewpoint. A tree is a 
hierarchical, simple structure: one thick trunk, then several branches, then many more twigs, up to multiple leaves. It is not merely a question of numbers, but a relational feature: each leaf is linked to only one specific twig and each twig to one specific branch. This many-to-one system results in a very simple, controllable, never spontaneous structure. After World War-II and all around the world, rationalist architects and planners found that "trees" were a very useful tool for planning neighbourhoods and whole cities. Dwellings, neighbourhoods, districts, towns, and metropolitan areas were imagined as Russian dolls, with implications for all sorts of urban systems, e.g. the road network-a hierarchy of local streets, collectors, arterial roads and freeways-. This type of order was intensely criticized by Alexander (1965) and other authors. Alexander hypothesized that the tree simplicity relates to the human mind difficulty to grasp and plan complex structures. However, he defended less hierarchical, more complex and subtle systems where overlaps and ambiguities could be possible and even common, to support the implicit spontaneity and randomness of social contacts in cities. This type of structure called 'semi-lattice' has been considered the trigger for social cohesion, solidarity, cross-fertilization, serendipity, creativity, resilience, aesthetics, and many other vital urban phenomena (Cullen 1961; Hertzberger 1991; Jacobs 1961; Mumford 1938). On the same page, the majority of planners and designers have been fighting to make these principles underpin their proposals despite the obstacle of inheriting very rationalist planning tools (Carpio-Pinedo et al. 2020; Fariña Tojo and Ruiz Sánchez 2002; Ruiz Sánchez 2002) ... until the Covid-19 pandemic arrived.

The Covid-19 crisis has called into question the structure of urban systems, along with other principles of sustainable cities like density and complexity, although these factors of urban sustainability can support the provision of services more efficiently and develop community-based solidarity networks to get over any crisis. Today many planners fear the return or intensification of sprawl and single-use zoning models as well as the intensification of private automobile demand.

The spatial approach for fighting the first wave of Covid19 in Spain has been disappointing and extreme (homebased lockdown), ignoring and neglecting the benefits of the local environment with regards to many other health issues. Because the network of interactions in cities is so dense and redundant, the stay-at-home rule leading to total lockdown has been the most common spatial approach: no semi-lattice, no tree, only cut leaves. If long-lasting, total lockdown may be counterproductive. Staying at home implies physical inactivity and sedentary lifestyles, loneliness and social isolation in all forms for an important share of population, attacking active lifestyles and mental health, especially for vulnerable groups or people with any kind of dependency.
Additionally, homes, buildings and close neighbourhoods and environments were found as unhealthy and uncomfortable spaces where it is impossible to combine household with productive work. Total lockdown approaches have also ignored the geographic and social asymmetries of the pandemic, which has reinforced social and health inequalities already present in the city (Comunidad de Madrid 2017). Later, the transition plan to lift the lockdown restrictions included measures like the possibility of a stroll within a 1 $\mathrm{km}$ radius around the home address, which is radically different depending on the type of urban fabric where one lives in. Further, the transition decisions were made on provinces as spatial units, which exceeded the scale of everyday life.

The second wave of Covid-19 has been approached differently, focussing on lockdown measures at the scale of the municipality but, in the case of Madrid city, also at the scale of basic health zones-administrative boundaries unrelated to local communities or the functional spatial system of the local environment. The results have included some grotesque sights, like one main street pavement under strict lockdown restrictions but not the opposite pavement.

Could we think of more imaginative lockdown spatialities to optimize the fight against the virus along with healthier lifestyles and the benefits of the local environment? We first argue that the city is not a tree but, in temporary pandemic situations, must sometimes be a tree. We propose a spatial rearrangement and fragmentation of cities based on the spatial analysis of the access to basic facilities by foot. The division of cities into basic functionally self-sufficient units ("local shelters") can inform an 'intermediate confinement' policy: if the pandemic is under control in the local environment, going out of home is allowed as long as staying within the boundaries of the 'local shelter' and maintaining basic social distance principles. Using GIS tools and data, we test this approach to the case study of the city of Madrid (Spain), which reveals the adequacy of the approach in some city areas but also some possible issues of the proposed approach and, in particular, spatial imbalances both as overlaps and lacks of access to basic facilities.

\section{Health and urban planning: a literature review}

\section{The city shaped by pandemics and other health issues}

Cities and urban infrastructures have historically evolved progressively due to multiple trends, dynamics, technologies and needs. However, health problems have been one of the major concerns to implement urban policies and regulations, and are at the core of the sheer birth of planning theory and practice in the nineteenth century. 
Table 1 Comparative urban health factors pre Covid-19

\begin{tabular}{|c|c|c|c|c|c|c|c|c|c|c|}
\hline \multirow[t]{2}{*}{10 Healthy Streets' indicators (2019) } & \multicolumn{6}{|c|}{$\begin{array}{l}\text { Delivering healthier communities } \\
\text { London (2017). Reduction of Euro- } \\
\text { pean diseases }\end{array}$} & \multicolumn{3}{|c|}{ Healthier neighbourhoods (2020) } & \multirow[t]{2}{*}{ Urban planning factors } \\
\hline & $\mathrm{C}$ & $\mathrm{R}$ & $\mathrm{O}$ & Th & A & MH & Walkable & Greener & $\begin{array}{l}\text { Coexist- } \\
\text { ence } \\
\text { spaces }\end{array}$ & \\
\hline Pedestrian from all walks of life & $\mathrm{x}$ & $\mathrm{x}$ & $\mathrm{x}$ & & & & $\mathrm{X}$ & & & Mobility \\
\hline Easy to cross & $\mathrm{x}$ & $\mathrm{x}$ & $\mathrm{x}$ & & $\mathrm{x}$ & & $\mathrm{X}$ & & & Mobility \\
\hline Shade and shelter & & & & $\mathrm{x}$ & & & & $\mathrm{x}$ & $\mathrm{x}$ & Microclimate urban conditions \\
\hline Places to stop and rest & & & & $\mathrm{x}$ & & $\mathrm{x}$ & & $\mathrm{x}$ & $\mathrm{x}$ & Urban design \\
\hline Not too noisy & $\mathrm{x}$ & & & & & $\mathrm{x}$ & $\mathrm{X}$ & & $\mathrm{x}$ & Environmental \\
\hline $\begin{array}{l}\text { People choose to walk, cycle and use } \\
\text { public transport }\end{array}$ & $\mathrm{x}$ & $\mathrm{x}$ & $\mathrm{x}$ & & $\mathrm{x}$ & $\mathrm{x}$ & $X$ & $\mathrm{x}$ & & Urban design \\
\hline People feel safe & & & & & & $\mathrm{x}$ & & & $\mathrm{x}$ & Land use, diversity \\
\hline Things to see and do & & & & & & $\mathrm{x}$ & & & $\mathrm{x}$ & Land use, complexity \\
\hline People feel relaxed & $\mathrm{x}$ & & & & & $\mathrm{x}$ & & $\mathrm{x}$ & $\mathrm{x}$ & Urban design \\
\hline Clean air & & $\mathrm{x}$ & & $\mathrm{x}$ & & $\mathrm{x}$ & & $\mathrm{x}$ & & Environmental \\
\hline
\end{tabular}

$C$ cardiovascular, $R$ respiratory, $O$ obesity, $T h$ thermal stress, $A$ acccidents, $M H$ mental health

Source: Author's elaboration accordingly to "Healthier Streets check indicators (2019), "Delivering healthier Communities in London" (2017) and "Guidelines for healthier public spaces for the elderly population. Recommendations in the Spanish context." (Higueras et al. 2019)

Three major types of interconnected public health issues exist in cities:

- environmental: produced by some source of pollutant emissions in water, air, electromagnetic waves, etc.;

- transmissible: attracting the world current attention due to Covid-19, but also including Ebola, flu, bubonic and other contagious diseases, where zoonosis is a major topic from the perspective of epidemiology;

- non-transmissible and non-communicable: identified as major public health issues in contemporary cities, affected by built environments and urban lifestyles, e.g. cardiovascular problems, obesity, mental health and loneliness.

Transmissible and contagious diseases like the Black Death or Spanish flu have justified the regulation of housing standards to improve ventilation and fight overcrowding, along with quarantines and social distancing (Nevius 2020; Strochlic and Champine 2020), the spatial control of certain activities with international links like trade (Bashford 2016; Rose 2020).

Transmissible diseases from animal to human has influenced the location and sanitary standards of certain facilities in cities, such as slaughters and markets (Connolly 2020). Because the Covid-19 outbreak in Wuhan has been related with a food market, this issue has gained attention recently (Huang et al. 2020).

The creation of water supply and sewage infrastructure (Gandy 2006), the relocation of pollutant industries out of residential areas, and the introduction of green areas in the city have been mainstream strategies for public health institutions and policymakers (Crompton 2013).

The Hygienist and Modernist Movements in the first half of XX century were aligned with these strategies (Wald 2020), but introduced new radical principles that affected sustainability and health in cities dramatically: dependence on automobile mobility, lack of pedestrian- or transit-oriented areas, land use zoning, social segregation (Shah 2010; Hendrickson and Mark 2020), spatial fragmentation, and increased disparities in terms of health in every city (Hutson et al. 2012; Lovasi et al. 2009). Further, the lack of a gender-sensitive perspective in planning for decades has resulted in the unequal access to basic services (Carpio-Pinedo et al. 2019; Horelli et al. 2000; Horelli and Wallin 2013).

For decades, promoting healthy cities has been a major objective for the World Health Organization (WHO 2010) as "places that are progressively increasing their physical, social and environmental well-being and that uses their own resources to improve them for all the people in the community". The Health 2020 strategy (WHO 2020), the European Territorial Agenda 2020 (Territorial Agenda 2011), and the European Disability Strategy 2010-2020 Action Plan (European Commission 2011) have underscored the role of urban planning and design in promoting healthy environments. However, the greatest attention until the Covid-19 crisis was the fight against sedentary lifestyles and risk factors for non-communicable diseases (Mayor of London 2017), as shown in Table 1. 
In that context, planning strategies towards healthier cities were focussed on promoting walkability and air pollution reduction through traffic restrictions, along with creating better conditions for 'active aging' (WHO 2002).

In line with this rationale, the Sustainable Development Goals (SDGs) 2030 (United Nations 2015) promote urban density, complexity, land use mix, proximity to green areas, public transport provision and facilities at accessible locations.

As Covid-19 pandemic sprawled on 2020 worldwide, the strategy must be updated and the consensus renewed. The aforementioned urban factors are now controversial: while some authors have stanched that SDGs-related factors such as density and public transport are incompatible with stopping contagion in large cities (Faus Onbargi 2020), others claim that only the dense city can preserve and articulate sanitary, solidarity and security measures (Sennett 2020).

Although there are some risk differences between the infectious and non-infectious diseases, density and complexity are essential factors of the desired city for many (Bosselmann et al. 1999; Jacobs 1961; Mumford 1938), and cannot be now stigmatized as simple risk factors, but defended and reconsidered as an opportunity to fight pandemic holistically. The experience of the Covid-19 crisis has proved the importance of neighbourhoods where individuals enjoy mutual support and solidarity networks, care and provision of food and goods (Davies 2020; Higueras and Pozo 2020; Lopez 2020).

\section{Response to pandemics in urban contexts}

In some contexts, the sanitary emergency is overshadowing the major health issues that were affecting pre-Covid-19 cities, as presented in the previous section. In this sense, urban planners, and policymakers all around the world have found an opportunity and are calling for creativity and new measures to promote healthier environments and Sustainable Development Goals rapidly (MacArthur 2020).

Total lockdown in countries such as Spain-where it has been restricted all non-essential displacement (Royal Decree 463/2020)-has negatively affected many people, and especially the most vulnerable. While authorities have considered "homes" as "shelters" against the virus, these spaces have shown important contradictions. Lack of housing quality (isolation, ventilation, light or space) and the restrictions to go out (social isolation, loneliness, and lack of physical activity) may have serious consequences on physical and mental health, which will start to be evaluated in the following months. Evidence shows that built environments are related to cardiovascular diseases (Franco et al. 2017; Lovasi et al. 2009). In addition, spatial disparities in Covid-19 are evident and have affected low-income, women and immigrant communities more intensely (Buchanan et al. 2020;
New York City Department of Health 2020), representing a major problem concerning health equity.

Many strategies have aimed to reduce the spread of infections while maintaining certain economic activities by establishing social distance regulations (Nishi et al. 2020). In this sense, the reduction of direct interactions might contribute to a higher isolation and segregation based on age, education or income differences (Block et al. 2020). Another strategy explored has been "balancing groups", which represents a redirection of individuals to alternative similar locations to balance the number of people gathering at each target area. In turn, other studies have confirmed the effectiveness of mobility restrictions so as to control the spread of the virus (Schlosser et al. 2020). Finally, many cities across the world have been implementing bespoke re-design projects for outdoor spaces to promote safer environments to walk or cycle, apart from pushing the sustainability agenda forward (NACTO and Global Designing Cities Initiative 2020; UK Government 2020).

In this paper, we explore the conditions that could support a better understanding of city structure and future spatial policies regarding mobility restrictions while maintaining the access to the majority of urban services.

\section{Local self-sufficiency: tree-liked city proposals in history}

The idea of conceptualising and shaping cities as a constellation of self-sufficient local communities was a popular planning principle for most of the twentieth century, but also a widely criticized one. Christopher Alexander's article "A city is not a tree" (Alexander 1965) underscored that urban structures must not be shaped as such hierarchically ordered spatial structures, but promoting different sorts of interconnectivity, complexity, overlaps and asymmetries (shaped as 'semi-lattices').

Alexander's main criticism is that the essential difference between the artificial (i.e., planned) and the natural (i.e., spontaneous) city, is a structural principle: while the natural city has the organization of a semi-lattice, we plan cities as tree structures, meaning that "within this structure no piece of any unit is ever connected to other units, except through the medium of that unit as a whole". The result is a city that obstructs liveability and variety (Jacobs 1961), as the artificial tree city concept destroys the natural and necessary overlap of human activities, which is best represented by semi-lattice structures. Another harmful assumption derived from tree-like thinking is that there is a deterministic relation between the designed object -the city- and its appropriation by social groups: "the physical layout of the plans, and the way they function, suggests a hierarchy of stronger closed social groups, ranging from the whole city down to the family, each formed by associational ties of different strength". 
Further, Alexander challenged the use of tree structures for city planning even in the case of administrative units, more precisely in terms of their political functionality.

However, some positive features of tree-structures can be found by a closer look to one of the examples in Alexander's paper. The "Neighbourhood Unit" (NU) appeared as a concept of self-sufficient community and became one of the most pregnant concepts in city planning. The NU was a concept coined by Clarence Perry in 1929, variously defined as a place, a community and a policy unit (Baffoe 2019). As a policy unit or tool, NU has been incredibly successful in twentieth century planning so it is explicitly found in Abercrombie's 1943 London Plan, the English New Towns from the 1950s to the 1980s, Costa and Niemeyer's Brasilia superquadras, Le Corbusier's Chandigarh Sectors and, more recently, in Duany and Plater-Zyberk's "New Urbanism". However, and as expected in a tree-like structure, NU reinforces the problems of limited variety, scarce overlapping, repetition, and hierarchy (Hillier 1988). In contrast, authors like Patricios (2002) argue that naïve social determinism (i.e., creating communities by design), should not be blamed on the original conception of $N U,{ }^{1}$ because the $\mathrm{NU}$ is primary an urban design concept aimed at changing the way undifferentiated low-quality peripheries were built. The focus was on the physical aspects of the concept, aiming at ensuring good life standards for the medium class. And this is where the concept could be helpful today: what are NU characteristics to provide a local environment with good living conditions?

The principles of the NU are well-known due to its success and Perry's graphic summary (Fig. 1):

- Focus on high-quality residential suburbs. The importance of open space, public facilities (school and community centre), shopping units at a walkable distance ( $R=1 / 4$ mile, "best when all sides are fairly equidistant from centre").

- Highlighting the definition of clear units of residential development, supported by size limitations ("it should house enough people to require one elementary school"), clear boundaries (surrounding roads), and by creating a community centre at the core ("only neighbourhood-level institutions").

\footnotetext{
${ }^{1}$ On the contrary, Patricios argues that the inclusion of social objectives within the aims of the NU was done lately by officials and practitioners, when it was adopted in the rest of the U.S., or in other countries around the world. In fact, over twenty organizations, from the Urban Land Institute, the American Institute of Architects, and the American Society of Planning Officials to the National Association of Home Builders, supported some or all of the neighbourhood unit principles (Solow et al. 1969, in Patricios 2002).
}

- Hierarchical principles, clearly expressed in facility and road classifications, where the NU boundaries were arterial streets.

As will be presented in the next section, these characteristics make the NU concept a suitable candidate in the definition of self-dependent "shelters", "intermediate confinement" units during pandemics. Further study and adaptation will be obviously needed, paying special attention to the relationship between facility areas and people's perception of what they consider their neighbourhood (Haynes et al. 2008).

\section{Methodology}

\section{Case study and data sources}

The case of the city of Madrid helps to test the approach. Madrid has been one of the cities where the Covid-19 pandemics during the first and second waves of 2020 have had the most dramatic impact in Spain (Spanish National Centre of Epidemiology 2020) and Europe. However, the advantages of choosing this case study relate more to the rich variety of urban environments with regards to density, land uses and morphology. The majority of trends in the History of City Planning have been applied in Madrid (Bataller Enguix et al. 2004) (Tables 2, 3).

Another reason is the longstanding priority of the local governments of providing good access to a variety of basic services and facilities (López de Lucio 1999) and the tested potential of the urban context to be reorganized as functional self-sufficient local environments (Hernández Aja 2007).

Open-data from Ayuntamiento de Madrid and Comunidad de Madrid have been used, corresponding to the city and regional levels of political action (Ayuntamiento de Madrid, n.d.; Comunidad de Madrid. Instituto de Estadística, n.d.). Both data sets can be considered 'open data', being easily accessible at no cost and with permits of reuse, transformation, and publication (Nugroho et al. 2015).

\section{A new spatial approach: local shelters for intermediate confinement}

This paper proposes a new spatial approach to fight pandemics while promoting healthier environments. The main argument is that, between the inevitable rapid spread of viruses in cities-as-usual and the extreme home-based lockdown, an intermediate approach is possible and desirable to fight the pandemic while promoting healthy lifestyles: staying in the local environment, strengthened as "local shelter". The following diagram (Fig. 2) illustrates this idea, using Alexander's type of diagrams. "Local shelters" have great potential 
Table 2 Urban factors risk with main European diseases and infectious diseases (post Covid-19)

\begin{tabular}{|c|c|c|c|c|c|c|}
\hline Main diseases in European Cities & High density & $\begin{array}{l}\text { Lack public } \\
\text { transport }\end{array}$ & $\begin{array}{l}\text { Low typologi- } \\
\text { cal variety }\end{array}$ & Lack of green areas & $\begin{array}{l}\text { Zoning -Land use } \\
\text { spatial distribution }\end{array}$ & $\begin{array}{l}\text { High } \\
\text { Mobility } \\
\text { by car }\end{array}$ \\
\hline Obesity & Medium & High & Medium & High & High & High \\
\hline Cardiovascular disease & High & High & Low & High & High & High \\
\hline Respiratory Diseases & High & High & Medium & High & Medium & High \\
\hline Heat or Cold Stress Shocks & High & Low & High & High & High & Low \\
\hline Accidents & High & High & Low & Low & Low & High \\
\hline Mental Health & High & High & High & High & High & High \\
\hline Infectious diseases post Covid & High & Low & Medium & Medium & High & Low \\
\hline
\end{tabular}

Source: Authors' own based on data from Delivering Healthier Communities in London (2007) adding infectious diseases post COVID-19

Fig. 1 Principles of the Neighbourhood Unit. Source: Authors' own (2020) redrawing Perry's scheme for Neighbourhood Units (Perry 1929)

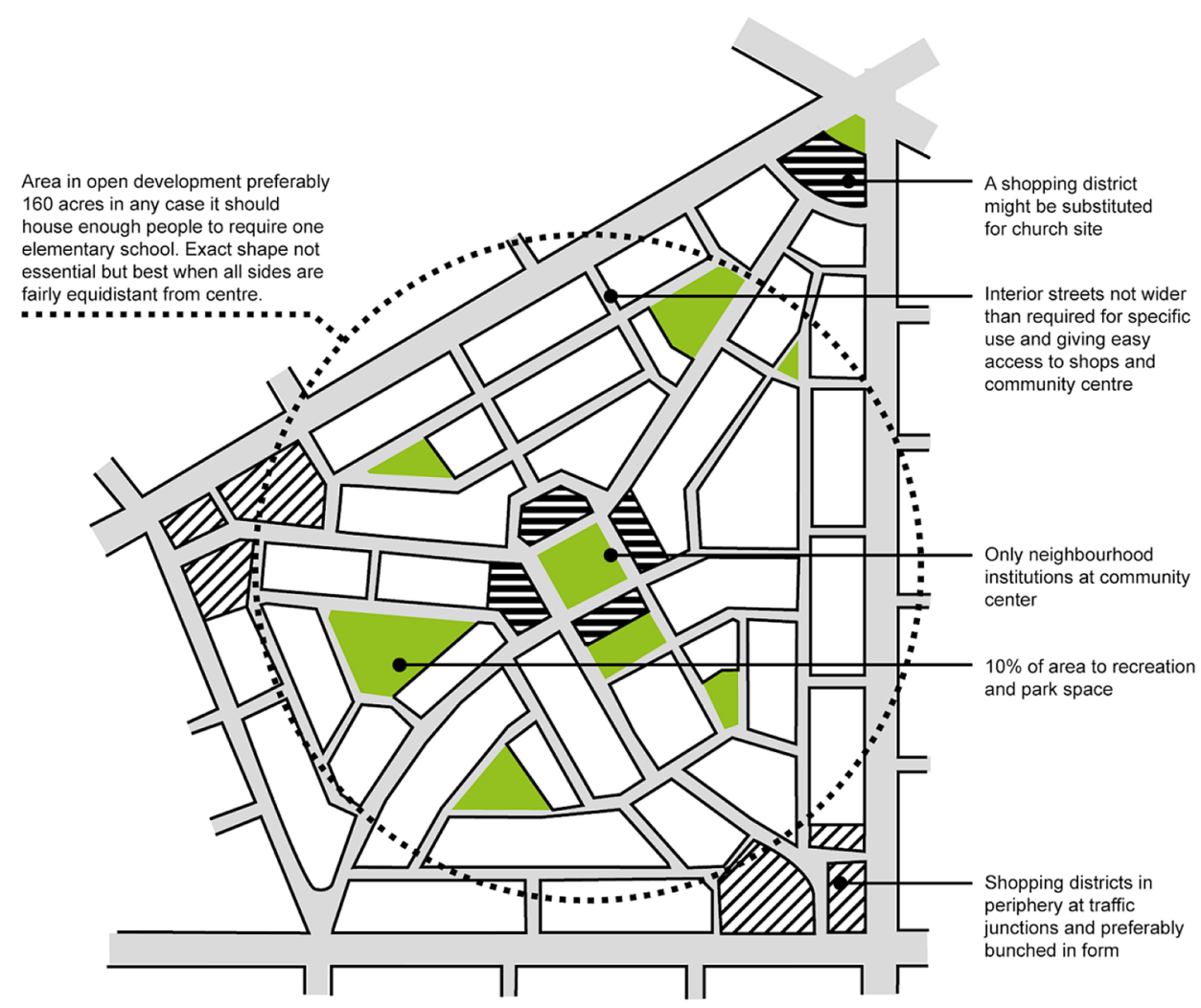

for reshaping public spaces and activating local economy towards healthier environments to improve quality of life.

Distant mobility should be reduced to the minimum, and transport infrastructure networks rethought as they can act as a great social-mixer (Carpio-Pinedo 2019), with network 'weak links' spreading the virus from one group (or neighbourhood) to another. However, if the city were reorganised temporarily as a collection of "neighbourhood units", as self-sufficient as possible, without contact from unit to unit, then these local environments could become real "local shelters" for an intermediate confinement that supports healthier lifestyles during the pandemic and with positive outcomes afterwards.

This means that the approach to authorizing/forbidding activities would be spatial rather than per type of activity: activities like going to work, shopping, and to a bar could be allowed, but only locally. People working in the area where they live could still go to work, but longer distance commuters would have to work from home or find a temporary working station locally. Imaginative, innovative, temporary deals could be possible, like a "desk-exchange", which would enable citizens to still have a place to work out of home. 


\section{CITY AS USUAL}

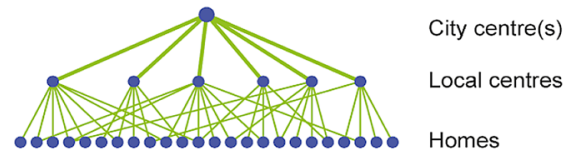

STAY AT HOME

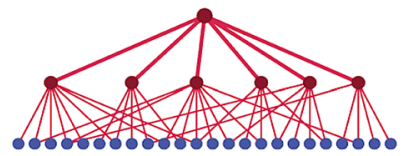

INTERMEDIATE CONFINEMENT

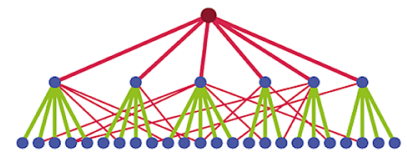

Fig. 2 Diagram of the new proposal for an intermediate confinement. In green, connexion between different scale of activity centres. In red, connections that might disappear during lockdown measures. In the diagram "city as usual", all the connections are free and open. In the second case, with the lockdown measure to stay at home, all these connections disappear. In the third case, intermediate confinement would stop bigger connections between urban areas and local accessibility remain open and free, with the possibility to enable certain restrictions in specific vulnerable or out-of-control areas. Source: Authors' own (2020)

"Local shelters" could be the right middle scale to fight the pandemic since they would optimize the other very important health issues (cardiovascular, mental, etc., especially for ageing population), as well as enabling the necessary social contact to develop a local network of solidarity, which may also be key to fight the socio-economic impact of the pandemic.

Further, a fragmentation of the city space into local shelters has the potential to support a smarter spatial management of the pandemic asymmetry. Out-of-control contagion in some areas would definitely lead to the total home-based lockdown that all Spanish citizens have recently experienced. However, if the virus is under control or not present in other areas, local movement and interaction could be allowed (Fig. 3).

This approach is based on a rationale and concepts that can be perfectly generalized and reproduced in other cities and countries, using similar data inputs and analytical steps. The case of the city of Madrid is appropriate because its great diversity of urban fabric types enables a more complete test of the approach.

\section{Analysis steps}

The first task has been identifying existing local centres, understood as the locations with high foot-access to a high number of basic facilities, to measure the accessibility enjoyed by city dwellers. These basic facilities are selected

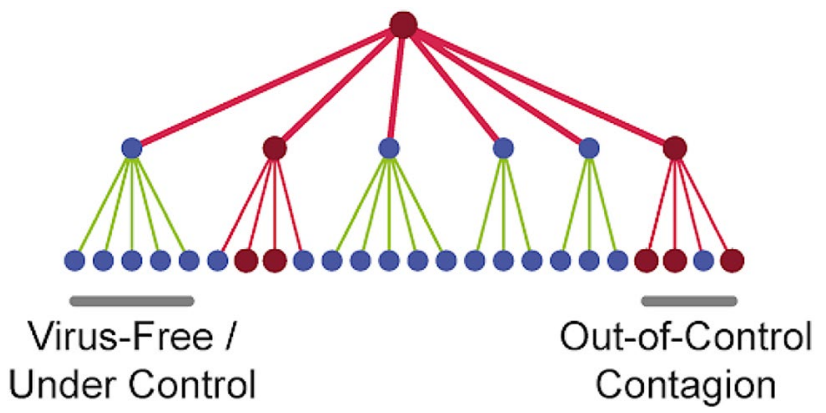

Fig. 3 Diagram of possible healthier and more efficient lockdown measures based on local shelters and intermediate confinement. Source: Authors' own (2020).

from municipal regulations of local equipments and services that should be included in urban districts such as educational and sanitary equipments, green spaces and parks, leisure and sportive centres and groceries and pharmacies. Hence, a synthetic opportunity accessibility index will be calculated, customising walkability indexes such as Walkscore (Carr et al. 2010) for health purposes. For each type of facility, service areas are drawn constrained by the street network, which is affected by street geometry-density and connectivity- and capturing on-foot accessibility better than Euclidean circles (Gutiérrez and García-Palomares 2008). Two distance thresholds have been considered (400 and $800 \mathrm{~m}$ ), corresponding to a 5- and 10-min walk respectively, and based on the local literature on spatial access to facilities (Carpio-Pinedo et al. 2019; Hernández Aja 1997). The closest service area $(0-400 \mathrm{~m})$ receives 2 points, while the second area $(400-800 \mathrm{~m})$ receives 1 point. As per previous literature (Carpio-Pinedo et al. 2019), access to shops was evaluated using the total number of shops accessible at 400 $\mathrm{m}$, as described in Table 3.

By summing up all points from individual facility accessibility evaluations, the total score represents the overall level of provision of basic services, understood here as 'local centrality' (Fig. 4), and a first approach of the spatial vocation of "local shelter".

The second task has been to draw possible boundaries for the "local shelters" that can sustain the "intermediate confinement" to face pandemics while enjoying the benefits of the local environment for other health issues, such as social exchange, physical activity and exercise, solar exposure and contact with nature. When possible, the local shelter boundaries are adjusted to the most intuitive urban barriers like motorways and large green areas, which are more context-aware physical or cognitive neighbourhood borders than the official administrative divisions.

Drawing local shelter borders has enriched the discussion, due to the very diverse situations related to the unequal levels of access to basic services across the city. Opposite 


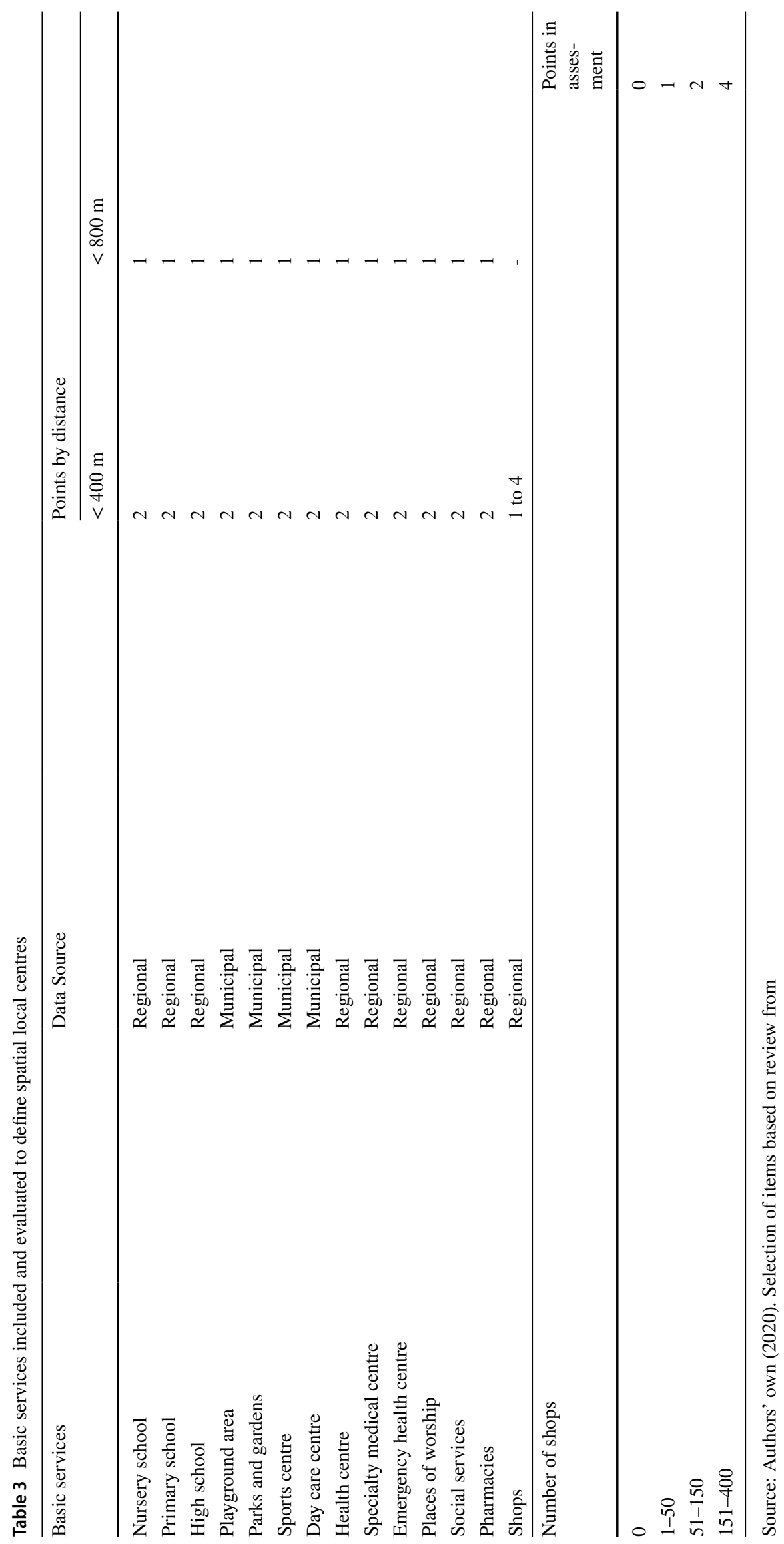



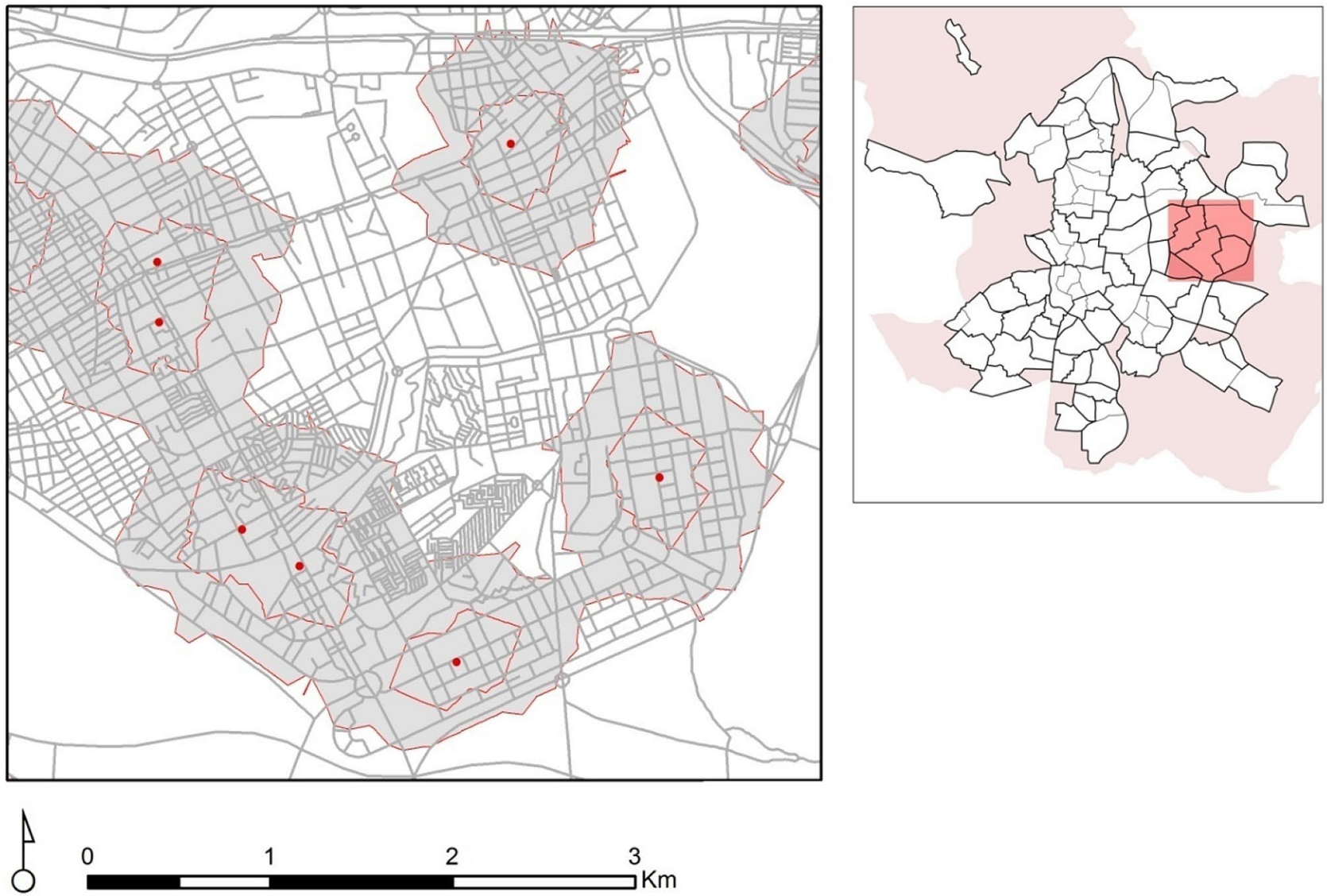

Fig. 4 Visualization of local centralities in San Blas-Canillejas District (Madrid East). Source: Authors' own (2020) using GIS tools

situations of both excess and lack of provision are not rare, and correspond with the diversity of urban fabrics. Further, by considering demographic data, it is possible to identify the local shelters where a higher number of vulnerable people live, and where more cautious policies and extraordinary resources may be targeted at. Likewise, the local shelters could be the base to monitor the number of contagions, so that intermediate confinement could be allowed in local shelters where the pandemic is under control whereas total home-based lockdown is limited to out-of-control areas.

\section{Results and discussion}

After calculating the total score of access to basic facilities, the first clear observation is that the existing official neighbourhood boundaries or health areas cannot possibly be the base to sustain the intermediate confinement proposed. The official boundaries have little to do with the distribution of facilities and the local centres deduced. Often these boundaries divide what we understand as a local centre in two or more official fragments, with no consideration of its functional potential. High streets are often the official boundaries dividing official neighbourhoods. However, could we imagine a regulation in which we are allowed to patronise one high street side shops but not the shops on the other side? That has already happened in Madrid's second wave local lockdowns. Maps in Fig. 5 show the official boundaries in contrast with the context-aware boundaries drawn as local shelters in this study.

After calculating the total score of access to basic facilities, a significant extension of land reached quite high values. Figure 6 shows in blue all areas with more than 15 points out of 30 (the maximum possible). Whereas a little extension of land got low scores $(<8$ out of 30$)$, most areas reach intermediate values (12-15 points), which means that a cut value to define a "local centre" should be higher. The shelter boundaries have been drawn with the purpose of not dividing areas with $20-30$ points, and when possible using areas of very low values to divide the urban territory (Figs. 7, 8, 9).

However, another important issue is rapidly evident: the diversity of city fabrics results in an unequal distribution of access to basic services, and thus of local centres. Whereas some local centres and potential urban shelters are almost 'naturally' defined, we can also identify many 

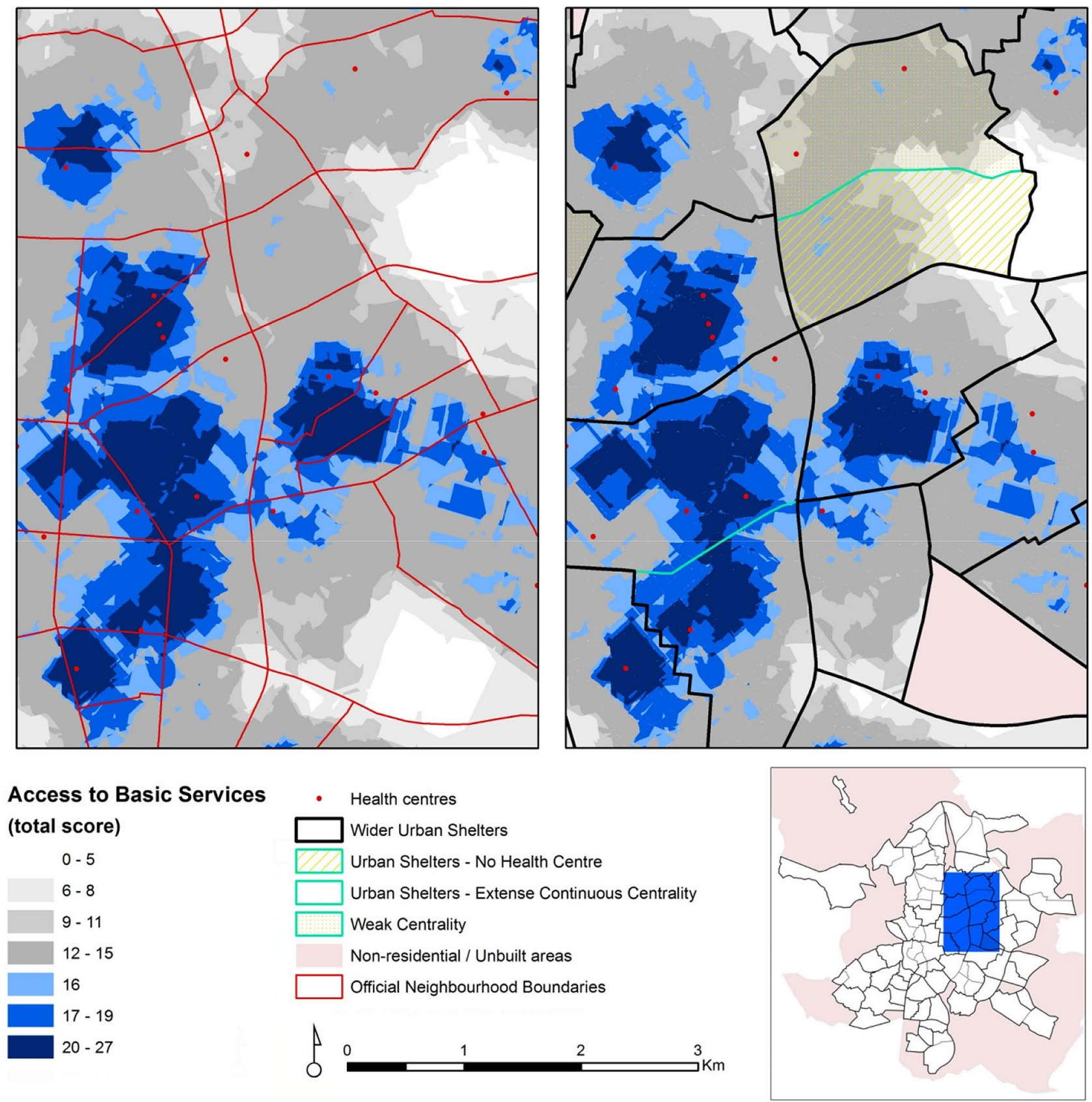

Fig. 5 Comparison between map with official boundaries of administrative neighbourhood boundaries (left) and map with boundaries for 'local shelter' areas (right). Source: Authors' own (2020) using GIS tools

other situations, both by excess or by lack of access to basic facilities.

First, extensive areas with very low total access were identified, which represent "weak centrality" or no centrality at all. This situation implies an obvious functional dependence of the not-so-close, closest local centre. In some cases, large areas are not equipped with a basic health centre, which is another issue of dependency in periods of pandemics. Low density, suburban areas or new still-unequipped developments are typical cases facing these two dependency problems.

On the opposite side, dense, diverse, central locations reach very high access to many basic services for extensive, continuous areas. Actually, too extensive for the purposes of this study, because such an intense provision of basic activities for such a large territory multiplies the risk of virus spread. In both cases, the decision was to 
Fig. 6 Spatial score of access basic services in Madrid.

Source: Authors' own (2020) using GIS tools
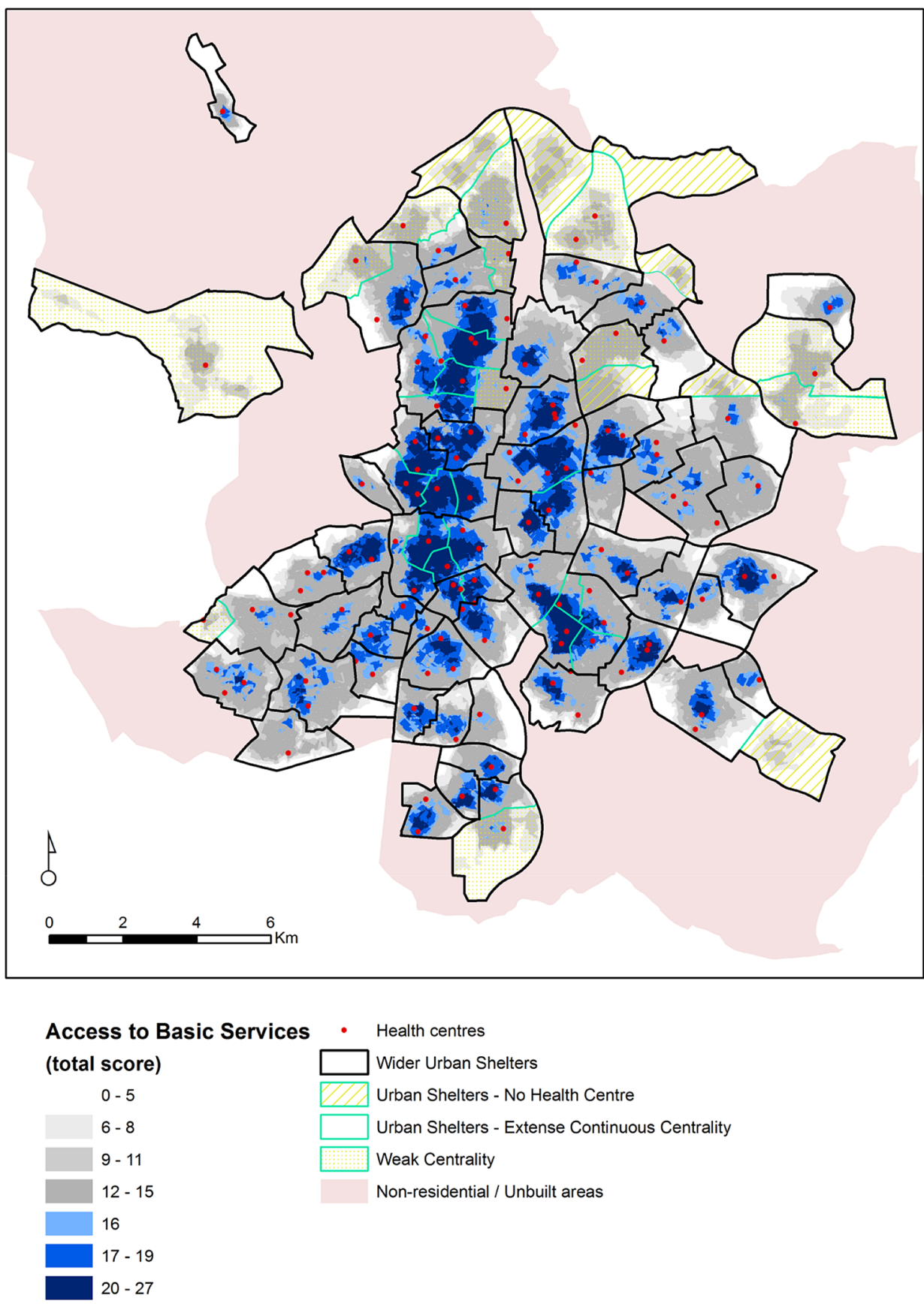

split these large areas (both continuous centralities and dependent areas) in smaller units.

However, this fragmentation is not ideal in terms of functionality and quality of life. Therefore, the proposal is that these types of local shelters could merge into 'wider local shelters', as long as all smaller shelters are virus-free or under control. The average area of the 90 smaller local shelters is 243.6 hectares, while the average area of the 58 wider local shelters rises to 376.13 hectares.

Another relevant question for discussion is how these functional areas fit with the unequal distribution of vulnerable groups in the city. The spatial analysis of the ageing ratio (share of $>65$ year-old population from the total amount), over-ageing ratio (share of $>80$ year-old population from the total of $>65$ year old) and index of dependency $(<16$ plus $>65$ year-old over the $16-65$ year-old $)$ shows several areas that are coincident with lack of health centres and weak centralities. On the other hand, there are certain areas like the city centre that present an extended continuous centrality while there are not very high levels of dependent or ageing population. This might be explained due to gentrification trends in the city centre showing a clear 


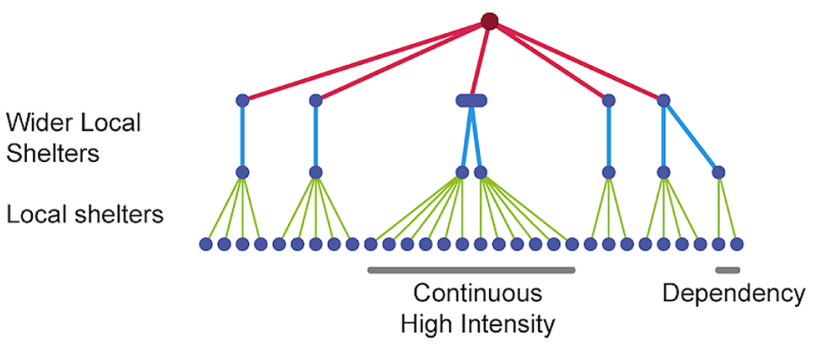

Fig. 7 Diagram of functionality and management for local and wider local shelters. Source: Authors' own (2020). In cases with lack of accessibility to local services, wider local shelters might be proposed in order to assure healthy environments and equal accessibility for citizens centre-periphery gradient in terms of ageing and over-ageing but not for dependency index. This preliminary analysis presents the question of health equity and management of equipment and services in dense cities, and reveals some service deficiencies from the local scale in the city of Madrid, which go beyond the pandemic crisis. This type of analysis could be the base for a cross-cutting reorganisation of the location of basic facilities, in order to create a more effective, balance network of spaces for proximity, care and active ageing. s

Indeed, the local shelters proposed for intermediate confinement can become an optimal intervention scale for promoting healthier neighbourhoods too, drawing on a fine-scale analysis of existing basic services and the everyday dynamics of the
Fig. 8 Diagram of functionality and management for local and wider local shelters. Source: Authors' own (2020)

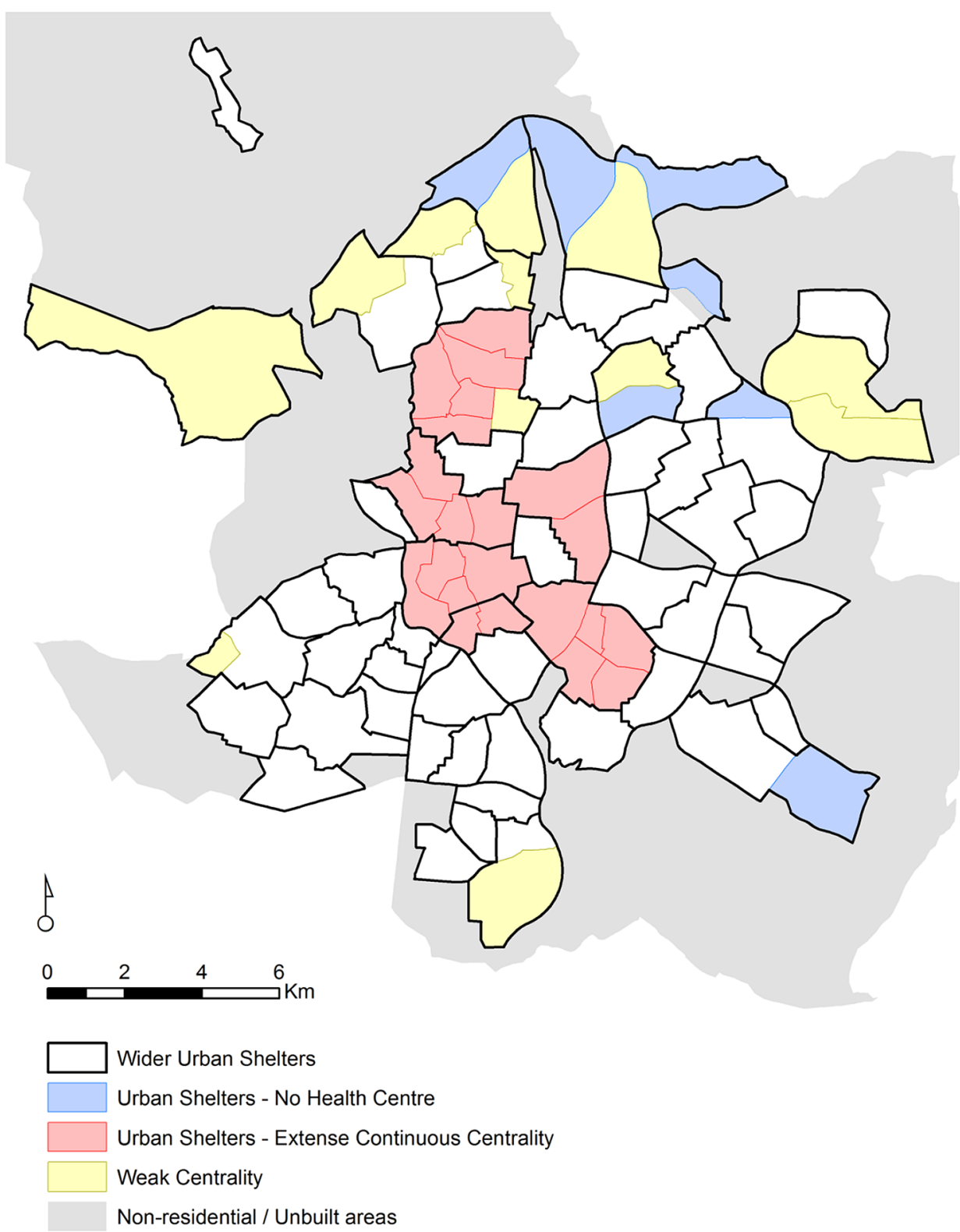



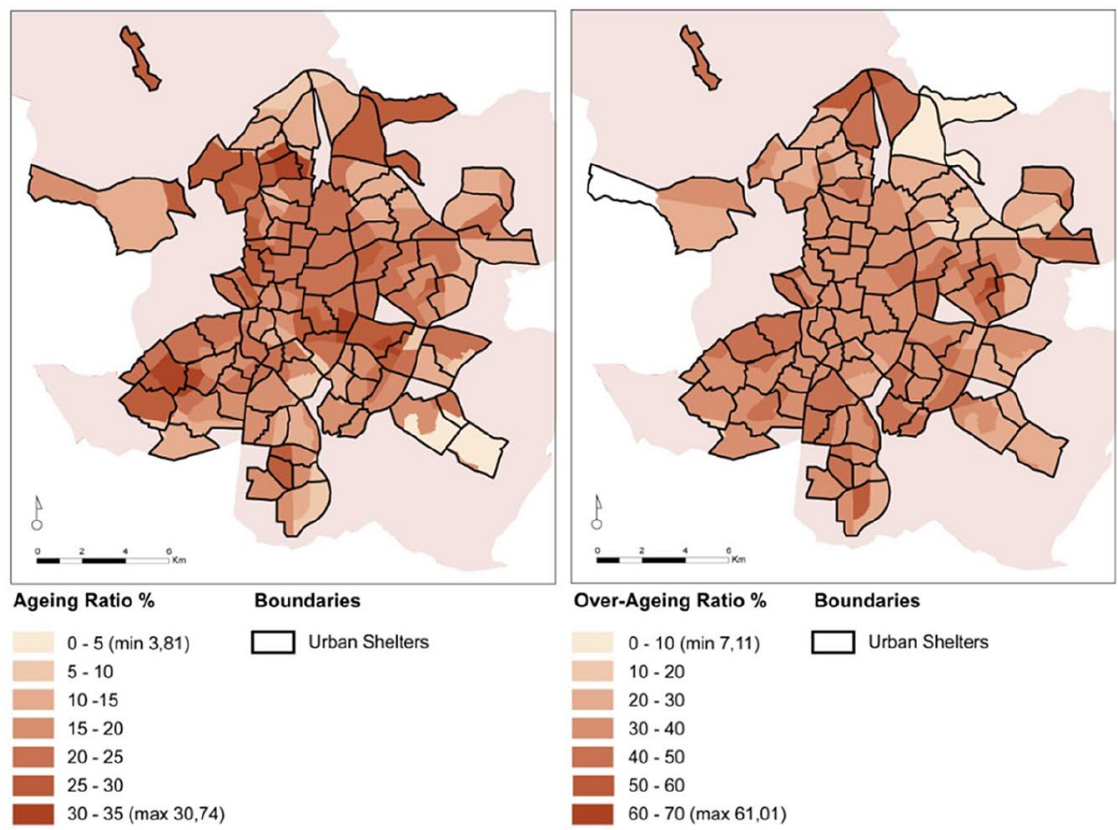

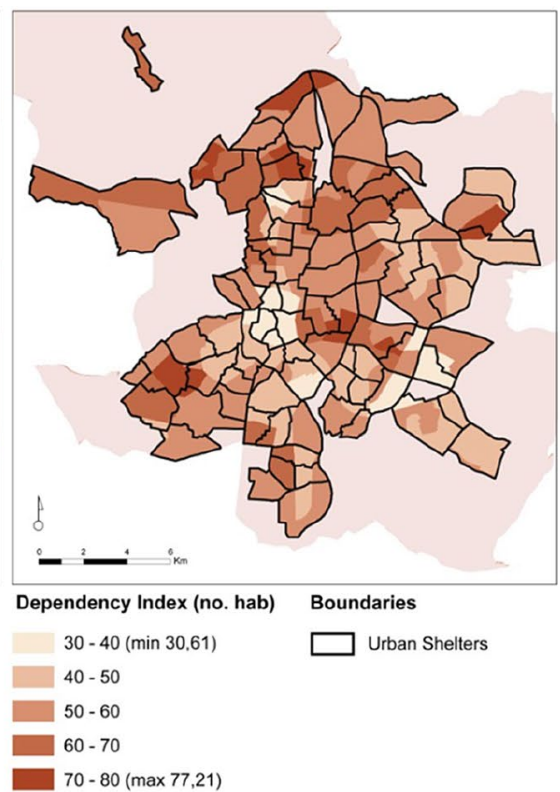

Fig. 9 Ratios of most vulnerable population to lockdown measures. First map (left) shows the Ageing Ratio (\%), which represents population of 65 years old or older from the total of the population. Second map (middle) shows the Over-Ageing Ratio (\%), which represents population over 80 years old from $>65$ years old population.
Third map (right) shows the Index of Dependency, which is defined as the sum of number of citizens younger than 16 years old and older than 65 years-old for 100 habitants of 16-64 years. Source: Authors' own (2020) using GIS tools from neighbourhood statistics of Ayuntamiento de Madrid (2018) city. The promotion of healthier environments at this scale is in line with the concept of the 15-min city (Hidalgo 2020) that is currently emerging as the trigger for sustainability in urban environments. Similarly, health management strategies are also evolving to the local scale following a more context-aware administration boundaries (Torrens 2018), and in relation to other small local environments units equivalent to the Barcelona's traffic-calmed "superblock" concept (Rueda, 2016), theorized for $400 \times 400-\mathrm{m}$ areas.

Both health and city management are getting to a more precise and better understanding of the built environment, health issues and data management at the local scale. Administrative divisions such as basic health areas are not context-aware and do not provide comprehensive information to analyse the impact on public health of built environment factors like the accessibility to basic facilities. A more-context-aware health management could optimise not only the management of services, facilities and data, but also constitute a more solid ground for health promotion action programs (Ministry of Health and Consumer Affairs and Social Welfare of Spain 2020).

\section{Conclusions and ways forward}

The initial aim of the paper was to explore the possibilities of moving from an extreme home-based confinement scheme to a more urban context-aware and healthy strategy: neighbourhood-based, reordering movement, provision of service and health monitoring in episodes such as the current Covid-19 crisis. The analysis of the on-foot accessibility to basic services in Madrid shows the opportunity of making compatible the sustainable city variables (density and complexity), with the definition of temporal 'intermediate confinement' self-dependent units to manage pandemic situations but also to improve health management actives thanks to a network of proximity providing services and equipments for health promotion.

Applying the principles of the neighbourhood unit, the 'intermediate confinement' in 'local shelters' has demonstrated its potential to face possible epidemic outbreaks following a smarter spatial strategy. Moreover, this approach confirms some major inequities in cities, being 
useful to identify the lack of basic services and healthy environments in certain neighbourhoods and in a context of increasing dependent populations. Thus, this approach can be the base to identify the areas requiring re-equipment and upgrading. The methodology could provide a more sensitive approach to combine the ongoing programs in many cities seeking regeneration, sustainability and health, in line with the new urban utopia of the '15-min city' (Pisano 2020; Willsher 2020).

Some ways forward could include:

- Testing the methodology in cities of different morphology, which may show dissimilar patterns of accessibility to basic services.

- Establishing a more complex, data-based and computer-assisted process to define the precise boundaries of 'local shelters', like the analysis of land use complementarity at the street-segment level (Carpio-Pinedo et al. 2021).

- Also, using local residents' insights framed in participation processes.

- The transition towards the coordination between the 'local shelters' defined and the official health system areas, at the local and district levels, or even evolving to a more effective system where health management is based on community actives and health prevention.

- The identification of key roads and streets to access the local facilities in each 'local shelter', and a protocol to increase its pedestrian capacity (with quick "tactic urbanism" measures first, a complete refurbishment later): measures to provide adequate, safe spaces during lockdown but also to improve connectivity between strategic spaces in the surroundings, to implement policies to take cars out of the public streets and, consequently, to promote walkable pathways in safe, comfortable and attractive streetscapes.

Local authorities can play a major role to face the challenges that will arise in future pandemic scenarios and this major decentralisation could support a smarter, healthier organization of the sanitary response for prevention, along with the development of local solidarity networks, and deliver a better quality of life and health conditions during these episodes in cities.

\section{References}

Alexander, C. 1965. A city is not a tree. Architectural Forum 122 (1): $58-62$.

Ayuntamiento de Madrid. n.d. Portal de Datos Abiertos del Ayuntamiento de Madrid. Last visit: May 29, 2017. http://datos.madrid.es/ portal/site/egob/.
Ayuntamiento de Madrid. 2018. Statistics and indicators for Neighbourhoods and districts. Open data. Last visit: June 1, 2020. https ://datos.madrid.es.

Baffoe, G. 2019. Understanding the Neighbourhood Concept and Its Evolution: A Review. Environment and Urbanization 10 (2): 393-402. https://doi.org/10.1177/0975425319859115.

Bashford, A. (ed.). 2016. Quarantine: Local and Global Histories. Macmillan International Higher Education.

Bataller Enguix, J., R. López de Lucio, D. Rivera Blasco, and J. Tejera Parra. 2004. Guía del urbanismo de Madrid S.XX. Madrid: Gerencia Municipal de Urbanismo. Ayuntamiento de Madrid.

Batty, M. 2013. The new science of cities. Cambridge, MA: The MIT Press.

Batty, M. 2020. The coronavirus crisis: What will the post-pandemic city. Environment and Planning B: Urban Analytics and City Science 47 (4): 547-552. https://doi.org/10.1177/239980832092691 2.

Block, P., M. Hoffman, I.J. Raabe, J.B. Dowd, C. Rahal, R. Kashyap, and M.C. Mills. 2020. Social network-based distancing strategies to flatten the COVID-19 curve in a post-lockdown world. Nature Human Behaviour 4: 588-596. https://doi.org/10.1038/ s41562-020-0898-6.

Bosselmann, P., E. Macdonald, and T. Kronemeyer. 1999. Livable streets revisited. Journal of the American Planning Association 65 (2): 168-180. https://doi.org/10.1080/01944369908976045.

Buchanan L., J.K. Patel, B.M. Rosenthal, and A. Singhvi. 2020. A month of coronavirus in New York City: See the hardest-hit areas. The New York Times.

Carr, L.J., S.I. Dunsiger, and B.H. Marcus. 2010. Walk score ${ }^{\mathrm{TM}}$ as a global estimate of neighborhood walkability. American Journal of Preventive Medicine 39 (5): 460-463.

Carpio-Pinedo, J. 2019. Multimodal transport and potential encounters with social difference: A novel approach based on network analysis. Journal of Urban Affairs. https://doi.org/10.1080/07352 166.2019.1662727.

Carpio-Pinedo, J., Hurtado S. De Gregorio, and I. Sánchez de Madariaga. 2019. Gender mainstreaming in urban planning: The potential of geographic information systems and open data sources. Planning Theory \& Practice 20 (2): 221-240. https://doi. org/10.1080/14649357.2019.1598567.

Carpio-Pinedo, J., M. Benito-Moreno, and P.J. Lamíquiz-Daudén. 2021. Beyond land use mix, walkable trips: An approach based on parcel-level land use data and network analysis. Journal of Maps 17 (1): 23-30. https://doi.org/10.1080/17445647.2021.1875063.

Carpio-Pinedo, J., G. Ramírez, S. Montes, and P.J. Lamiquiz. 2020. New urban forms, diversity, and computational design: Exploring the open block. Journal of Urban Planning and Development. https://doi.org/10.1061/(ASCE)UP.1943-5444.0000555.

Cerdà, I. 1991. Teoría de la Construcción de las Ciudades. Cerdà y Barcelona. Volumen I. Ministerio para las Administraciones Públicas y Ajuntament de Barcelona.

Cervero, R., and K. Kockelman. 1997. Travel demand and the 3Ds: Density, diversity, and design. Transportation Research Part D: Transport and Environment. 2: 199-219. https://doi.org/10.1016/ S1361-9209(97)00009-6.

Comunidad de Madrid. Instituto de Estadística. n.d. Nomecalles Nomenclátor oficial y Callejero. Last visit: May 29, 2017. http:// www.madrid.org/nomecalles/DescargaBDTCorte.icm.

Connolly, J. 2020. Global Crisis Leadership for Disease-Induced Threats: One Health and Urbanisation. Global Policy.

Crompton, J.L. 2013. The health rationale for urban parks in the nineteenth century in the USA. World Leisure Journal 55 (4): $333-346$.

Davies, A. 2020. The pandemic could be an opportunity to remake cities. Wired.

Cullen, G. 1961. Townscape. New York: Reinhold Pub. Corp. 
European Commission. 2011. European Disability Strategy 2010 2020. A Renewed Commitment to a Barrier-Free Europe. COM (2010) 636 final. https://eur-lex.europa.eu/legal-content/EN/ TXT/?uri=celex:52010DC0636.

Fariña, Tojo J., and Sánchez. J. Ruiz. 2002. Orden, desorden y entropía en la construcción de la ciudad. Urban 7: 8-15.

Faus Onbargi, A. 2020. How urban lifestyles made Spain so vulnerable to Covid-19. Oxford Urbanists.

Fernández-Ballesteros, R. 2008. Active ageing. The contribution of psychology. (Hogrefe and Huber, Ed.). Göttingen, Germany.

Fincher, R., and K. Iveson. 2008. Planning and diversity in the city. Redistribution, recognition and encounter. New York: Palgrave.

Franco, M. 2017. Heart healthy hoods project. Social and Cardiovascular Epidemiology Department, University of Alcalá de Henares.

Gandy, M. 2006. The bacteriological city and its discontents. Historical Geography 34: 14-25.

Granovetter, M.S. 1973. The strength of weak ties. American Journal of Sociology 78 (6): 1360-1380. https://doi.org/10.1086/225469.

Gutiérrez, J., and J.C. García-Palomares. 2008. Distance-measure impacts on the calculation of transport service areas using GIS. Environment and Planning B: Planning and Design 35 (3): 480 503. https://doi.org/10.1068/b33043.

Haynes, R., K. Daras, R. Reading, and A.P. Jones. 2008. Modifiable Neighbourhood Units, Zone Design and Residents' Perceptions. Health \& Place 13 (4): 812-825. https://doi.org/10.1016/j.healt hplace.2007.01.002.

Hendrickson, C., and M. Mark. 2020. Will Covid-19 Rebalance America's Uneven Economic Geography? Don't Bet On It. Brookings. Retrieved from: https://www.brookings.edu/blog/the-avenu e/2020/04/13/will-covid-19-rearrange-americas-uneven-econo micgeography-dont-bet-on-it/. Accessed 3 Mar 2021.

Hernández Aja, A. 2007. Madrid centro: división en "barrios funcionales." Cuadernos de Investigación Urbanística (CIUR), 50. http:// polired.upm.es/index.php/ciur/article/view/265.

Hernández Aja, A. (dir.). 1997. La ciudad de los ciudadanos. Madrid: Ministerio de Fomento.

Hertzberger, H. 1991. Lessons for Students in Architecture. Rotterdam: 010 Publishers.

Hidalgo, A. 2020. Le Paris du quart d'heure. Dossier de presse. Paris en Commun. https://annehidalgo2020.com/wp-content/uploa ds/2020/01/Dossier-de-presse-Le-Paris-du-quart-dheure.pdf.

Horelli, L., C. Booth, and R. Gilroy. 2000. The EuroFEM Toolkit for mobilizing women into local and regional development. Helsinki: Helsinki University of Technology, Centre for Urban and Regional Studies.

Horelli, L. and S. Wallin. 2013. Gender-sensitive E-planning for sustaining everyday life. In Fair shared cities. The impact of gender planning in Europe. Fair shared cities: the impact of gender planning in Europe. pp. 231-248. Surrey and Burlington: Ashgate Publishing Ltd.

Higueras E., E. Román, and J. Fariña. 2019. Guidelines for healthier public spaces for the elderly population. Recommendations in the Spanish context. Ministry of Health of Spain.

Higueras, E. and E. Pozo Menéndez. 2020. Urbanismo y salud: ¿Son las ciudades europeas resilientes a las pandemias? The Conversation.

Hillier, B. 1988. Against Enclosure. In Rehumanizing Housing, Butterworths, London, ed. N. Teymur, T.A. Markus and T. Wooley, 63-88. https://doi.org/10.1016/B978-0-408-02039-8.50009-9.

Huang, C., Y. Wang, L. Xingwang, L. Ren, J. Zhao, Y. Hu, et al. 2020. Clinical features of patients infected with 2019 novel coronavirus in Wuhan. China: The Lancet. https://doi.org/10.1016/S0140 -6736(20)30183-5.

Hutson, M.A., et al. 2012. Metropolitan Fragmentation and Health Disparities: Is There a Link? Milbank Quarterly 90 (1): 187-207.

Jacobs, J. 1961. The death and life of great American cities. New York: Random House.
Land Use Consultants and Centre for Research into Environment and Health. 2007. Delivering healthier communities in London. London: HUDU.

López de Lucio, R. 1999. Madrid 1979-1999. La transformación de la ciudad en veinte años de ayuntamientos democráticos. Madrid: Gerencia Municipal de Urbanismo. Ayuntamiento de Madrid.

Lopez, M. 2020. Our Role as Planners During a Pandemic. Pueblo Planning.

Lovasi, G.S., M.A. Hutson, M. Guerra, and K.M. Neckerman. 2009. Built environments and obesity in disadvantaged populations. Epidemiologic Reviews.

MacArthur, A. 2020. Urban Planners urging major rethink due to Covid-19 pandemic. Global News Canada.

Mayor of London. 2017a. Healthy streets for London. London: Transport for London.

Ministry of Health and Consumer Affairs and Social Welfare of Spain. 2020. Localiza Salud. Health resources map. Government of Spain. https://localizasalud.mscbs.es/maparecursos/main/Menu. action.

Mumford, L. 1938. The culture of cities. London: Secker and Warburg.

NACTO and Global Designing Cities Initiative. 2020. Streets for pandemic response and recovery. https://globaldesigningcitie s.org/covid-19-resources-center/\#english.

Nevius, J. 2020. New York's Built Environment Was Shaped by Pandemics. Curbed NY.

Nishi, A., G. Dewey, A. Endo, S. Neman, S.K. Iwamoto, M.Y. Ni, Y. Tsugawa, G. Iosifidis, J.D. Smith, and S.D. Young. 2020. Network interventions for managing the Covid-19 pandemic and sustaining economy. Proceedings of the National Academy of Sciences of the United States of America 117 (48): 29993 29994. https://doi.org/10.1073/pnas.2014297117.

Nugroho, R.P., A. Zuiderwijk, M. Janssen, and M. de Jong. 2015. A comparison of national open data policies: Lessons learned. Transforming Government: People, Process and Policy 9 (3): 286-308. https://doi.org/10.1108/TG-03-2014-0008.

New York City Department of Health. 2020. COVID-19 Data: Health.

Perry, C.A. 1929. "The neighbourhood unit", Monograph 1 in Committee on Regional Plan of New York and its Environs (ed.) Neighbourhood and community planning. Regional survey. Volume VII. Committee on Regional Plan of New York and its Environs, New York, pp. 20-141.

Pisano, C. 2020. Strategies for post-COVID cities: An insight to Paris En Commun and Milano 2020. Sustainability 12 (15): 5883. https ://doi.org/10.3390/su12155883.

Roos D. 2020. Social distancing and quarantine were used in Medieval Times to fight the Black Death. History.

Rueda S. 2016. La supermanzana, nueva célula urbana para la construcción de un nuevo modelo funcional y urbanístico de Barcelona. Agencia de Ecología Urbana de Barcelona. http://bcnecologi a.net/sites/default/files/proyectos/la_supermanzana_nueva_celul a_poblenou_salvador_rueda.pdf.

Ruiz Sánchez, J. 2002. Complejidadurbana y determinación. Estructurascomunicativas y planeamientourbano en el desarrollodelÁreaMetropolitana de Madrid. Madrid: Universidad Carlos III de Madrid y BoletínOficial del Estado.

Sample, H. 2012. Emergency Urbanism and Preventive Architecture. In Imperfect health: The medicalization of architecture, ed. G. Borasi and M. Zardini, 231-250. Canada: Canadian Centre for Architecture Montreal \& Lars Muller.

Schlosser, F., B.F. Maier, O. Jack, D. Hinrichs, A. Zachariae, and D. Brockmann. 2020. COVID-19 lockdown induces disease-mitigating structural changes in mobility networks. Proceedings of the National Academy of Sciences of the United States of America 117 (52): 32883-32890. https://doi.org/10.1073/pnas.2012326117. 
Sennett, R. 1977. The Fall of Public Man (Re-edition). London: Penguin Group.

Sennett R. 2020. In Shenker J. Cities after coronavirus: how Covid-19 could radically alter urban life. The Guardian. https://www.thegu ardian.com/world/2020/mar/26/life-after-coronavirus-pandemicchange-world\#_=_.

Spanish Ministry of Health. 2020. Enfermedad por coronavirus, COVID-19. Technical report. Coordination Centre of Alerts and Sanitary Emergencies Centre. Updated on March 17, 2020.

Strochlic N., and D.C. Riley. 2020. How Some Cities' Flattened the Curve' during the 1918 Flu Pandemic. History.

Territorial Agenda. 2011. Territorial Agenda of the European Union 2020. Towards an Inclusive, Smart and Sustainable Europe of Diverse Regions. Informal Ministerial Meeting of Ministers responsible for Spatial Planning and Territorial Development on May 19, 2011. Hungary.

Torrens L. 2018. Envejecimiento y mejora de la gestión pública: el caso de Barcelona y las supermanzanas sociales. Comunicación original presentada por el autor durante la Jornada TransJus sobre "Envejecimiento, ciudad y derechos". Celebrated on April 9, 2018 in Facultad de Derecho, Universidad de Barcelona, Spain.

Urban Heritage Conservation and Sustainable Development Research Team. 2020. Urban Function-Spatial Response Strategy for the Epidemic - A Concise Manual on Urban Emergency Management. SEU Key Laboratory of Urban and Architectural Heritage Conservation, Ministry of Education of China.

UK Government. 2020. Coronavirus (COVID-19): safer public places - urban centres and green spaces. Ministry of Housing, Communities \& Local Government. https://www.gov.uk/guidance/safer -public-places-urban-centres-and-green-spaces-covid-19/5-manag ement-of-green-spaces

United Nations. 2015. Sustainable Development Goals SDG. https:// sustainabledevelopment.un.org/?menu $=1300$

World Health Organization. WHO. 1948. International Health Conference (1946), New York, on 19 June - 22 July. Official Records of WHO, 2: 100.

WHO. 2002. Active Ageing. A Policy Framework. Madrid. https:// apps.who.int/iris/bitstream/handle/10665/67215/WHO_NMH_ NPH_02.8.pdf?sequence $=1$.

WHO. 2010. Urbanization and health. Bulletin of the World Health Organization (BLT) 88 (4): 241-320.

WHO. 2020. Brochure - Implementing Health 2020: 2012-2014. https://www.euro.who.int/en/health-topics/health-policy/healt h-2020-the-european-policy-for-health-and-well-being/about -health-2020/brochure-implementing-health-2020-2012-2014.

Willsher, K. 2020, February 7. Paris Mayor unveils "15-Minute City" plan in re-election campaign. The Guardian. https://www.thegu ardian.com/world/2020/feb/07/paris-mayor-unveils-15-minut e-city-plan-in-re-election-campaign.

Wirth, L. 1969. Urbanism as a way of life. In Classic essays on the culture of cities, ed. R. Sennett, 143-164. Englewood Cliffs, NJ: Prentice-Hall.
Young, I.M. 1990. Justice and the politics of difference. Princeton: Princeton University Press. https://doi.org/10.2307/1964259.

Publisher's Note Springer Nature remains neutral with regard to jurisdictional claims in published maps and institutional affiliations.

Jose Carpio-Pinedo is a Researcher at the Department of Urban and Regional Planning_-Universidad Politécnica de Madrid. He has also been a visiting researcher in the UC Berkeley-City and Regional Planning department and São Paulo University-Urban and Regional Economy Lab (NEREUS). His research ranges over urban proximity dynamics; walkability; multi-modal network analysis/accessibility patterns; land use and transport coordination; public space configuration and retail location. Jose has worked as a Planning and Transport consultant for Atkins Ltd., London and the Consorcio Regional de Transportes de Madrid (Madrid Public Transport Authority).

Elisa Pozo Menéndez Architect and Urban Planner, Universidad Politécnica de Madrid and Institut Français d'Urbanisme (IFU, Francia). Researcher in group ABIO (UPM) Architect and urban planner with specialized in Sustainability and Environment. She has realized master studies of "Villes Durables" (Institut Français d'Urbanisme, 2014) and "Bioclimatic Architecture and Environment" (UPM, 2019). She is researcher and $\mathrm{PhD}$ student on urban health and Dementia-Friendly Communities. She collaborates with different architecture and urban planning studios and she teaches visualization data and workfIows in several masters and posgraduate courses. Since 2006 she has been engaged with different NGOs and associations working on social inclusion and participation.

Francisco José Lamíquiz Daudén Professor at the Urban Planning Department of the School of Architecture, at the Universidad Politécnica de Madrid (UPM). He is an Architect by UPM, holds a M.Sc. by UCL (Bartlett School) and a Ph.D. by UPM. His field of research and professional work is the relationship between citizens, urban space, mobility and accessibility.

Ester Higueras García is Doctor of architecture, full-time professor at Universidad Politécnica de Madrid. She is Professor in the master Environment and Bioclimatic Architecture and in the master Territorial Planning. She is team member of the research group ABIO (Bioclimatic Architecture in a Sustainable Environment-UPM). Since the lecture of her $\mathrm{PhD}$ thesis in 1997, she has been combining both theory and practice in projects of environmental planning, bioclimatic urban design, passive strategies applied to urban scale, cultural landscape and environmental policies. 